\title{
22
}

\section{THE IDEA OF SPACE AND URBAN SEQUENCES}

\author{
The Case of Parma
}

\section{Carlo Gandolfi}

In order to set up and begin an essay on the city or - in the present case - on the public space and its declinations, relationships, and instances, it seems legitimate to use the words written by Ludovico Quadoni in 1954 in the magazine "Comunità" on what is the city, its essence, its character. Starting from this short opening allows to set the reasoning on the European city and what we could mean, precisely, by public space. Not only that; I would like them to serve as a "zero degree" of this reasoning, which should bring us back to the human essence of urban space, even before its being a place of speculation and the absence of quality and specificity:

The city is composed of everything, the city is everything: it is a total continuous architecture, which is not only that of churches and palaces; there is a space in the city; there is an order, a scale, a proportion, a dimension, a rhythm for each city; together with the trees there is a light, a color, an air, a smell that characterize it, all sensations that surround us, together with the soul of men and things. ${ }^{1}$

(Quaroni 2019, 13)

Starting from this, it is legitimate to ask why the medium-sized European city - a definition, it must be said, which is extremely extensive and not necessarily completely accurate in relation to further, complex parameters - can be considered a qualitatively appreciable type of city. In this sense, the necessary question for an architect turns to which characteristics, be they physical, perceptive, or experiential (Lynch 1962 and 1981; Barthes 1957), unite these cities.

What constants, if any, characterize the qualitative indicators of the urban space without the most recent suburban condition?

A first answer could be found in the character of the historical fabric and in its specificity, the result of characterizing languages and architectural registers, settlements where rites - facts $^{2}$ - have found the space of their existence, of reiteration, of fixation over time precisely because it is in the city that the human experience becomes a tangible sign and 
memory (Halbwachs 1950, 130-137). According to Kahn $(2002,136)$ - also mentioned in Perulli (2009, 11-112):

The foundation of architecture coincides with the making of spaces at the service of human institutions. In the aura of silence and light, the aspiration to be, to do and to express, recognizes the laws that open up the possible [...]. Tension is released from desire, from waiting for what has not yet been created.

historically, it is in the city that the rules of community life begin to exist and the institutions and cultural heritage of civilizations grows. Precisely for this reason, these cities give us and from them we inherit what, in summary, we could define a sort of geometric trust, a character, and a frequency (Lefebvre, H. 1996) already accorded to a place over time, regardless of any possible obedience to the contemporary. These are the essential components of the so-called urban landscape (Passarge, 1930; Cullen 1961; Tricart 1963) (Figure 22.1).

Starting from the conviction that one of the main factors determining the quality of living in the medium-sized European city lies in the relationship between private and public spaces, or in the structuring of open spaces and, in this case, in the sequences of spaces $^{3}$ in relation to collective buildings and monuments connected thereto, this essay intends to examine the theme with respect to a specific urban case. The idea of extrapolating urban sequences as a significant datum with respect to the study of the city in its entirety finds support, among others, in Chabot (1948), Lavedan (1936), Lynch (1960), and Cerasi (1973).

The city of Parma is an exemplary reference as it can enclose a series of factors in the relationship between urban dimension and territorial scale which, as we will see, sanction starting from its development in Roman times, a place with a particular characterization of open spaces and their sequences in relation to architectural facts, readable as perceptive cornerstones, so to speak, diluted within the compact fabric of the city.

An approach to the concept of space is necessary in order to concentrate the reasoning on this precise investigative condition. In Design of cities, Bacon (1967) begins by stating that there are two mutually integrated entities underlying the architectural project: matter and space.

Returning to the idea of urban space, it is now necessary to try to define what we mean by open spaces and how they are defined from time to time by assimilating a physical denotation - open space, in fact - to a conceptual one, or public space.

Starting from the idea of voids, we could say, in the first instance, that public space is $e v$ eryone's space. ${ }^{4}$ This nature of absolute collectivity does not mean, however, that public space is intended for everyone to the extent that every particular will can be pursued there; rather, it is true that the responsibility for the preservation of public space and its enrichment lies with the community (Hertzberger, 2009, 12). Public space is inseparable from monumental sequences and is defined by urban architecture. Belonging to everyone therefore means that it is the space where the community recognizes itself, knowing that it is possible to meet, express, discuss there. It is a space for use, transit, rest, travel, or pause; it is the space where the temporality of the private individual participates in the collective, assimilated within it: only in the public space can this sort of social alchemy occur. The construction of this definition is only apparently simple, but this level of complexity appears sufficient for our reasoning 

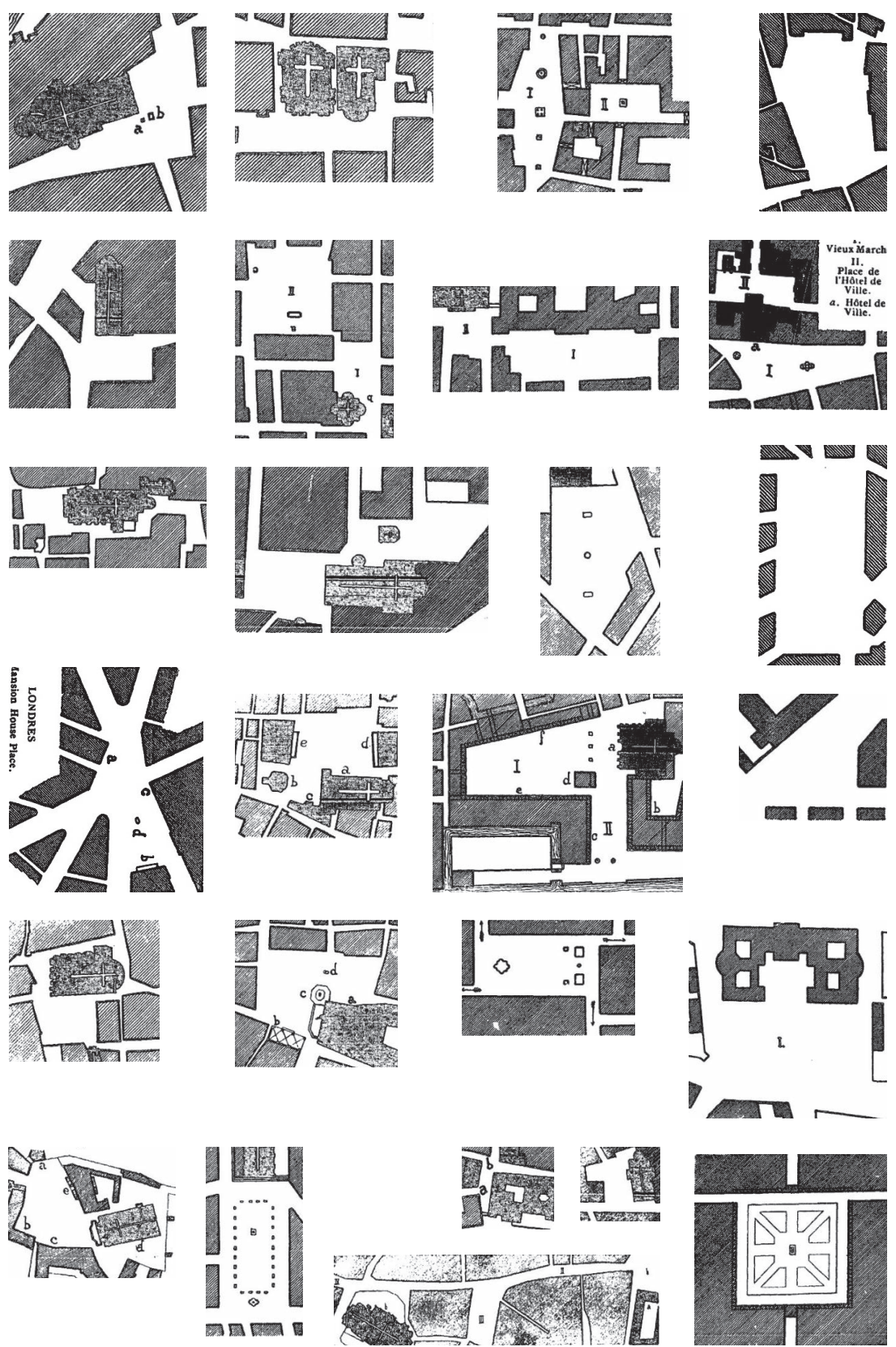

FIGURE 22.1 Comparison between some of the schemes developed by Camillo Sitte that show the relationships between spatial invasions in the urban fabric, the monuments, and the urban texture within which they are innervated.

while underlining, in abstract terms, that the space must in any case have a dialogue with an external reality since, as geographical, historical, experiential matter (and therefore artificial in itself), it sees matter acting thereon as the causa efficiens of its very structure. ${ }^{5}$ 
In this sense, it is important to re-understand the elements that structure - or arm, so to speak - the very meaning of open space in the city. To better understand the sequences and gradient of meaning that populates them in their alternation, contrast, overlapping, these elements must be assumed as indispensable parts of a compositional whole, of a compact and stratified historical fabric within which, in time, facts that could be defined as surgical or incisions, emptying, capable of allowing, precisely that linearly growing fabric, scalar rejections and revolutions within the relationships between parts and in the sequences of the spaces themselves. ${ }^{6}$ It is the movement - over time - within the planimetric space that allows the user to walk through the succession of the scenic sequences of the city in the theatrical dimension of the city itself. Being a space-time experience, movement carries a unit of measurement therewith which is the use of the city through walking. This pace allows for understanding the sequential story.

Starting from the 15th century, the square (Garzoni 1996) - constituted by the availability of that empty space within the urban fabric highly populated with meaning - assumed the role it still plays today, in the virtual and remote era: "a space in which the city expresses the necessary and irrepressible diversities" (Amendola 2010), a meeting place, a place where the community recognizes itself and, metonymy of the people, wrapped in the architecture that encloses it and delimits it through its system of façades (Pierini 2008), providing this space with the backdrop of memory, a vertical space-surface in turn, limen between what is inside and what is outside.

But the most common type of void in the urban texture is the street. If the square can present invariant elements or dimensional, formal, and figural similarities, the street presents heterogeneous characters in most cases precisely due to its directional, connective nature and, in fact, not immediately definable in terms of length (just think, in the case of Parma, of the carrier Via Emilia). The road leads and distributes, innervates the urban texture in the territory, and in following it, the sequences in which large spaces, gardens, interruptions, accidents, and movements appear.

In the contemporary city, there are also other elements, not properly named or definable, not contained within a specific lexicon, also referred to by Giuseppe Samonà as place-spaces. ${ }^{7}$ He himself hopes that

[...] the profound images that are formed there must indicate with their semantic iconism all the physical and mental aspects of the localized space of a system defined with direct perception in the streets, squares, gardens, and more forming the visible reality by walking inside it to establish its differential characters; all in the context of a controllable perception, given by the semantic inconsistency of the various images of each place-space, in which the quality of the existing structures, those of the population living there and the aims of the rationalization and enhancement of housing and services to be included.

To better understand the scope and design potential of these place-spaces, it may be useful to resort to the historic city and, in the case of Parma, to try to identify some notable spatial sequences in the relationships between urban fabric, architectural fact, road, square and garden or voids with other possible connotations. ${ }^{8}$

Even before the birth of perspective, painters sought to immortalize the urban scene, depicting life and events as if to fix their memory. To better understand what we mean by spatial or urban sequence, we refer to a passage from Sergei Eisenstein's Montage Theory in 
which the Russian director equates the space of the Acropolis with the oldest of films with respect to the duration of the impression that comes from the shots chosen by Auguste Choisy, in his History of Architecture (Choisy 411-419), of which Eisenstein reports extensive integral excerpts (Landsberger 2015).

From this series of planimetric and perspective schemes, it is in fact possible to understand how the reciprocal arrangement of the individual temples in the space composes an urban scene that is highly refined in compositional and proportional terms. The sequences of urban spaces have specific characteristics both from a dimensional and linguistic point of view; it is as if each city were staging its own action in space. Consider, for example, the case of Florence, where the alternation of spatially encroaching architectural elements generates an authentic architectural promenade capable of generating that sense of collectivity and belonging to the place, characterizing the quality of the open spaces in relation to the buildings overlooking them. After passing Ponte Vecchio, you walk along a segment of Lungarno along the river and then reach the large urban interior of the Uffizi up to Piazza della Signoria to then enter Piazza Duomo from the side, with the Baptistery on the left and the Cathedral of Santa Maria del Fiore on the right. The experience of this last great "excavation" in the urban fabric leads to Via dei Servi, along which you reach the Church of the Santissima Annunziata and then Ospedale degli Innocenti. Here is the expansion of open spaces in relation to the architectural buildings which, heterogeneous in form and function, sum episodes and generate a sequence full of meaning, densely populated with religious, administrative, representative, and welfare functions.

As for Parma, its history as the capital of the Duchy (1545-1860), and which today is entrusted not only to the arbitrary and to languages less deposited in the times of construction, but rather to the profit of the construction industry, but sees in the absence of monumental facts, urban landmarks, a fact about which we must necessarily confront within order to comprehend the articulated relationship between monument, forma urbis, and territory. Starting from the Roman cardo-decumano structure that maintains its role as an organizational factor through Via Emilia, the intra monia area is divided by the presence of Parma's torrential watercourse that defines the roles of the two parts of the city: the one based on the ancient Forum, of a representative and administrative nature, and that of the Oltretorrente, used as a residential fabric and with large service structures such as the 13th-century Ospedale della Misericordia (Figure 22.2).

Observing the historic city, still legible in its form and its overlapping, it is possible to identify, in particular, three urban sequences that can also be interpreted as succeeding and interacting with each other. The attempt will be to interpret the architectural elements in their juxtaposition and complementarity (Figure 22.3).

The first sequence is designed to allow reaching the center starting from the large green area of Parco Ducale, and which today is entrusted not only to the arbitrary and to languages less deposited in the times of construction, but rather to the profit of the construction industry, but sees in the absence of monumental facts, urban landmarks a fact about which the project must necessarily confront, leaving the Palazzo behind, crossing Verdi Bridge over Parma, up to facing the tripartite cavity of the blind side of the colossal Palazzo della Pilotta. Begun by the Farnese family in 1539, it constitutes the ideal threshold of an open interior still to be reached, after which you are covered by the mighty mass overlooking the shadowy cavity that gives access to Teatro Farnese, the National Gallery, and the Palatine Library. It is a unique pass-through atrium, a sort of urban diaphragm that is part of the 

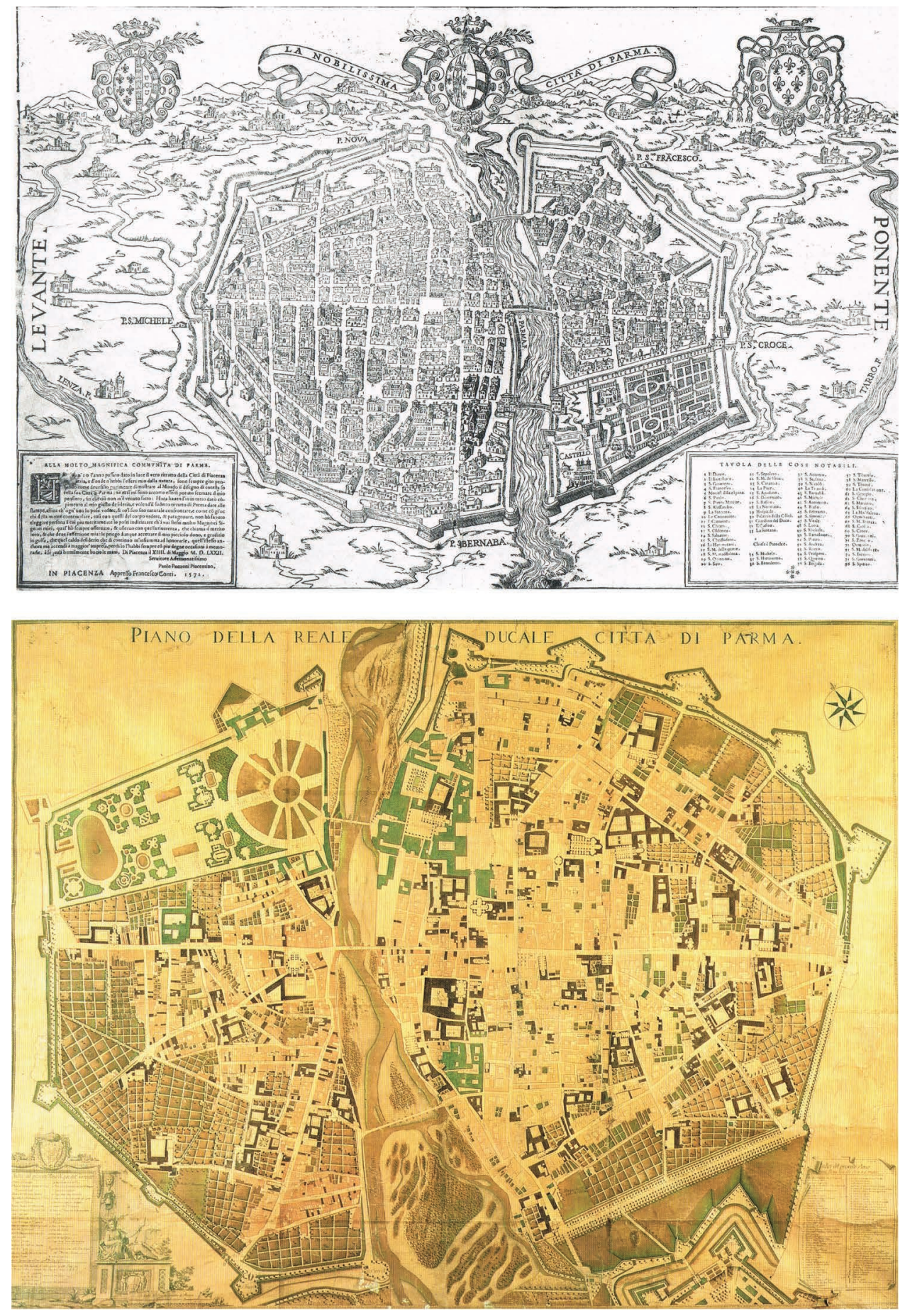

FIGURE 22.2 Above, Paolo Ponzoni, bird's eye view of Pamra, 1572. Below, Piano della Reale Ducale Città di Parma, second half of the 18th century, monumental complex of the Pilotta-National Archaeological Museum of Parma (image courtesy of the Minisetero for Cultural Heritage and Activities). 


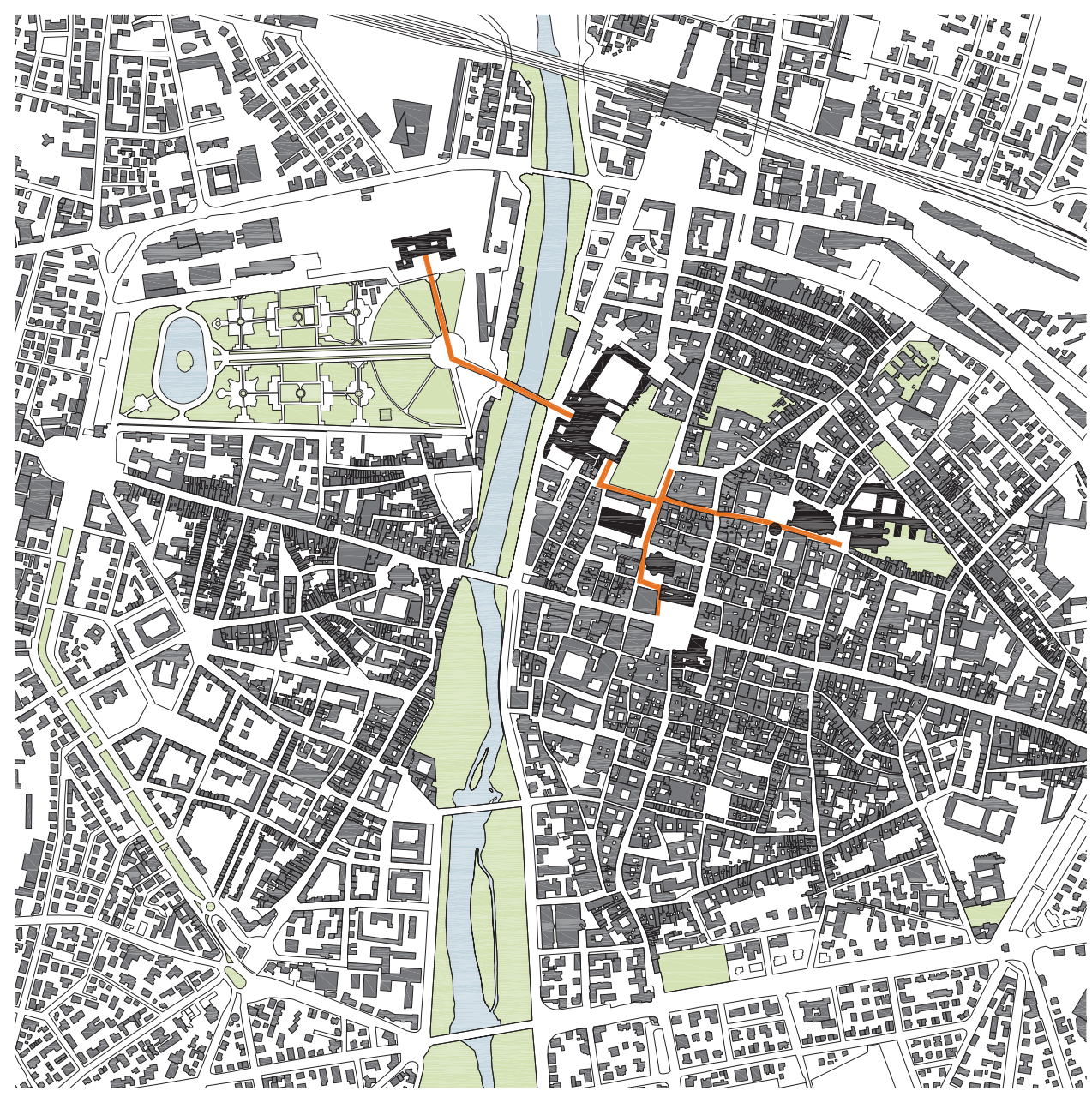

FIGURE 22.3 DrawingofthenucleusofthehistoricalcityofParma.Originalscaleofthedrawing:1/100. The buildings highlighted in the chapter are highlighted in black and the sequences in orange.

Palazzo's device. Once you have passed this hypostyle space you reach the equally mighty open courtyard that claims the absence of the church and opens onto Piazzale della Pace. It is a sort of passage of state: from the large green area, the visual connection with the natural element of the river basin, a sort of decompression chamber, anticipation of another urban interior, that of the courtyard which in turn overlooks a large void that seems to be an anticipation of the Teatro Regio first and the Baptistery-Cathedral-Church sequence of San Giovanni Evangelista (Figure 22.4).

Starting from this large empty space, Piazza della Pace, it is possible to head toward the founding center of the city, the place of the Forum, where the cardo crosses Via Emilia along the 19th-century Bettoli façade of Teatro Regio erected at the behest of Maria Louise of Austria. A few steps and another presence bursts into the fabric that becomes gradually more compact: the Basilica di Santa Maria della Steccata built starting from 1521 with a Greek Bramante plan, after which you enter the space of the ancient Forum through a sort 


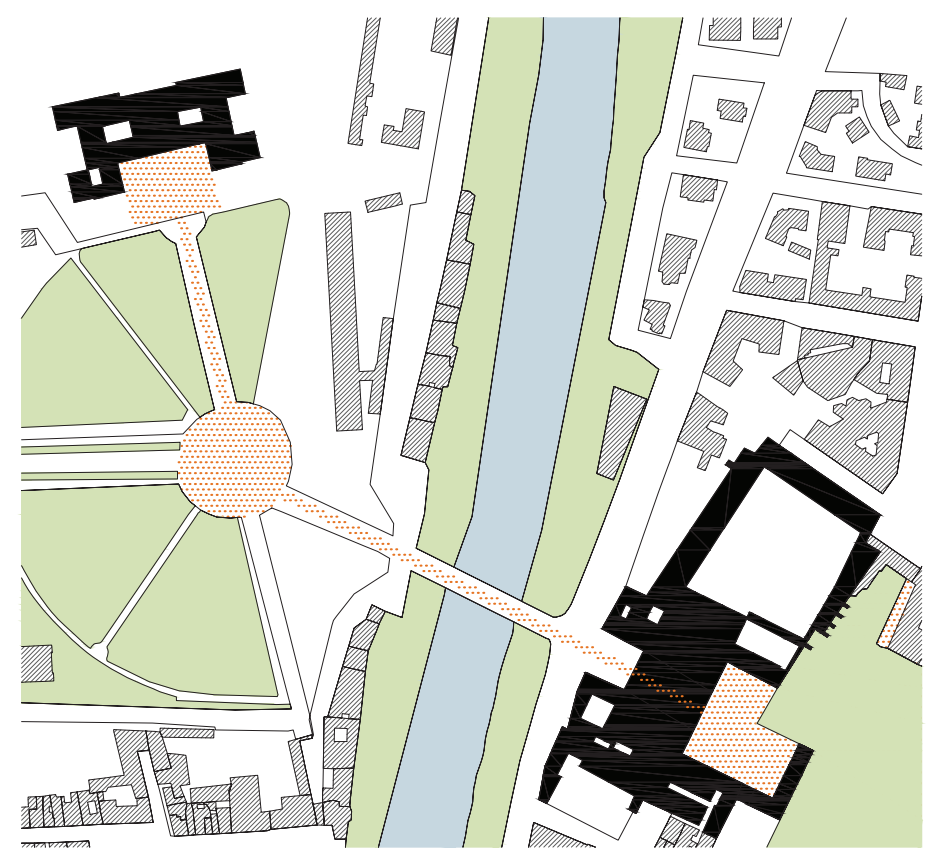

FIGURE 22.4 First sequence: from Palazzo and Parco Ducale until Piazza della Pace. Original scale of the diagram: $1 / 333$.

of isthmus that runs alongside the Governor's Palace and fixes a diagonal that points to the Town Hall overlooking the Portico del Grano. This is the physical and conceptual center of the city, a large regular void crossed by Via Emilia with the University active since the 11th century located just a few meters away (Figure 22.5).

From the great void of Piazza della Pace, there is a third, extraordinary sequence, this time grafted onto a longitudinal axis that sees - starting from the broken court of the complex of the Pilotta. This third sequence highlights, as the drawings show, in particular how urban space finds dilations and restrictions linked to the presence of major urban events of monumental magnitude. It emerges, in this case, a legitimate question about the architectural quality that the historical city preserves, as shown in the images of the inlaid views, and which today is entrusted not only to the arbitrary and to languages no more deposited in the times of construction, but rather to the profit of the construction industry, but sees in the absence of monumental facts, urban landmarks a fact about which the project must necessarily confront, passing under the southern portico and skirting the facade overlooking the side of the Piazza della Pace - the succession of the Baptistery, the façade of the Duomo, and the Palazzo of the major episcopal seminary, until discovering, precisely in progressive sequence, the façade of the church of San Giovanni Evangelista, in a perspective thread that relates the elements to each other, making them become one another's staircase (Figures 22.6 and 22.7).

Some quick historical and chronological notions give the idea of the complexity the city generates in history, within an area that can be covered in a few minutes on foot. These urban sequences are able to restore the complexity of the forms of the urban project 


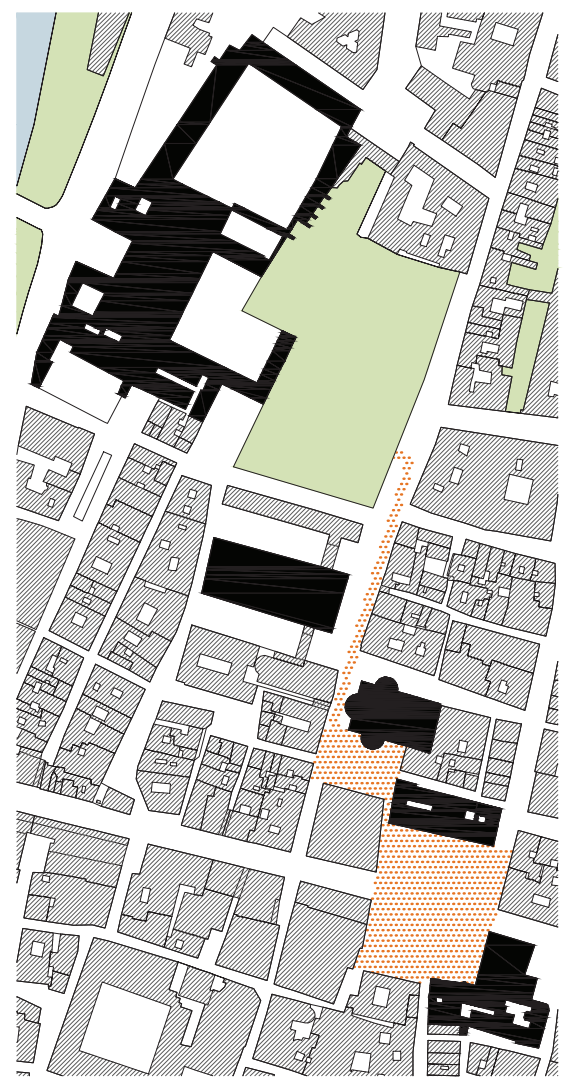

FIGURE 22.5 Second sequence: from Piazza della Pace to the ancient forum. Original scale of the diagram: $1 / 333$.

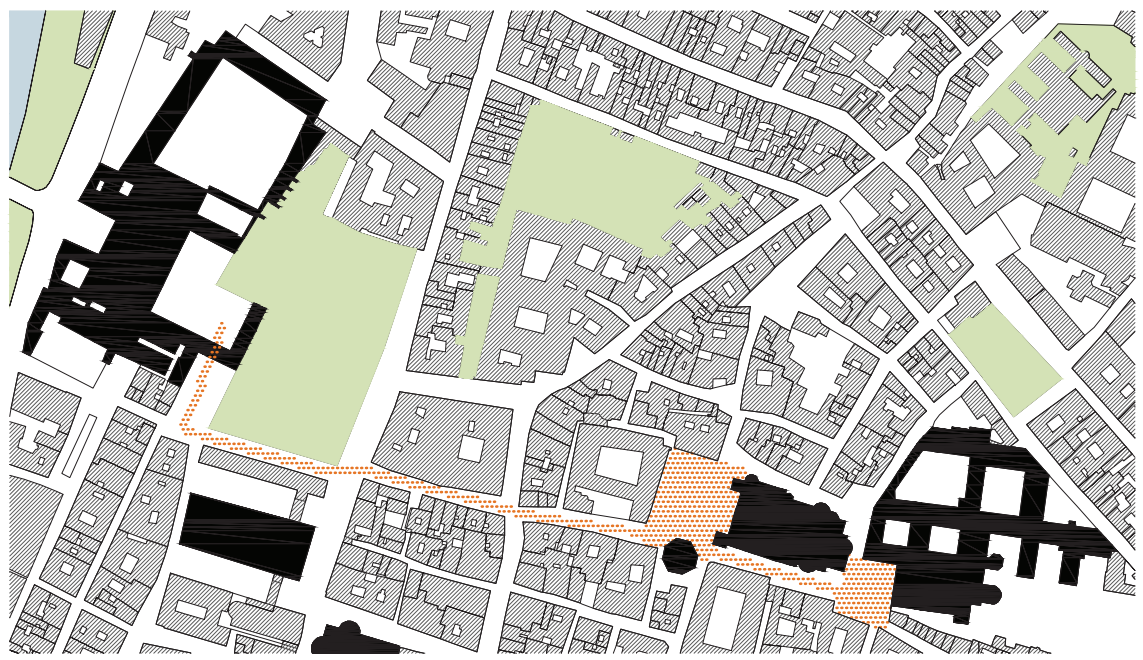

FIGURE 22.6 Third sequence: from Pilotta to San Giovanni Evangelista. Original scale of the diagram: 1/333. 

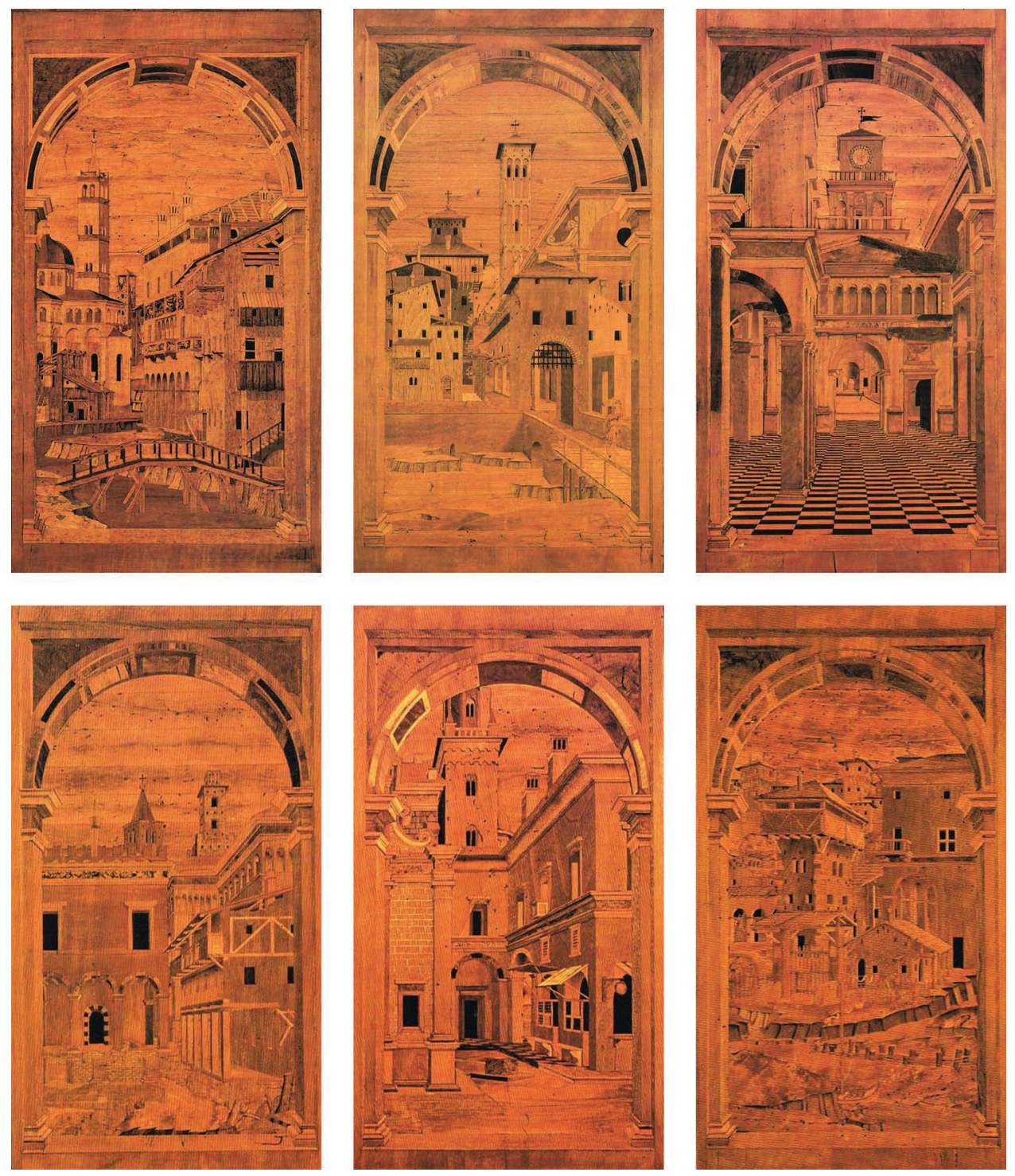

FIGURE 22.7 Inlays of the stalls of the choir of the Church of San Giovanni Evangelista carved and inlaid by Marcantonio Zucchi and Pasquale Testa. They are illustrated probable past of the city of the 15th century and bear horizons, streets, paved squares, arcades, canals, towers, doors, and human figures. Like ancient shots, they represent frames of ideal film sequences.

starting from its founding instances. The space between the architectures is characterized by fissile backdrops that hide courtyards and other more intimate interior spaces. These urban sequences innervate the urban fabric that we could define as secondary, made up of lesser structures, roads, and what we could call, starting from Alberti's definition according to which the house is a big city and the city a small house, a large distribution system on an urban scale that connects episodes while keeping the identity of the built structure compact. 
Identifying these sequences allows us to measure spatial encroachments and architectures, understanding the importance and value of that truly public space. It is a question of welcoming the possibility of making the very space that becomes the place manifest and of which, today, the city seems to want to give up in favor of logics far from the slow passing of human life.

\section{Notes}

1 Quaroni's text was originally published in issue 25 of the magazine "Comunità" in 1954, the magazine founded by the "Movimento Comunità" in 1946 and then directed by Adriano Olivetti and later by Giorgio Soavi and Renzo Zorzi.

2 As regards the term facts, see Rossi, A. 1966, especially the extraordinary definition of architecture on pages 4-5: "Architecture is the fixed scene of human affairs, loaded with the feelings of generations, public events, private tragedies, new and ancient facts."

See - among others - as regards studies relating to urban systems: Sitte (1889), Sitte (1952), Aymonino (1975), and Mumford(1977).

3 The idea of extrapolating urban sequences as a significant datum with respect to the study of the city in its entirety finds support, among others in: Lynch, K. 1960. The image of the city. Cambridge: Technology Press \& Harvard University Press; Cerasi, M. 1973. La lettura dell'ambiente, Milano: CLUP; Lavedan, P. 1936. Géographie des villes. Paris: Gallimard; Chabot, C. 1948, Les villes. Paris: Collins.

4 On the theme of public space, see, among others, Brandão, Carrelo, and Águas (2002). On the degrees of interaction between man and space, see, among others, De Sessa (1990), Vieira de Almeida (1963, 2008), Sommer (1969), Portas (2005), and Massey (2005). On the relationship between space and place, see Leveratto (2018).

5 See, among others, Rizzi (1999).

6 In its heritage, in conceptual terms, from the Roman forum and the Greek agora, it etymologically refers to the reference to the Latin platea "central area of the theater, broad street".

7 Gianugo Polesello specifies:

[...] places that do not possess the architectural finiteness, the geometric and stylistic absoluteness of the artifact, but which appear as more complex structures, also difficult to describe with graphic language (the perspective) or with written language. They are places that can appear in the form of intersections without being punctual.

(Polesello 1989, 183-186)

See also Polesello 1985.

8 For a reading of urban space in this sense, see Kostof (2009).

\section{Bibliography}

Amendola, G. 2010. Tra Dedalo e Icaro. La nuova domanda di città. Rome-Bari: Laterza, 132.

Aymonino, C. 1975. Il significato delle città. Roma-Bari: Laterza.

Bacon, E. N. 1967. Design of Cities. New York: The Viking Press.

Banzola, V. 1978. Parma la città storica. Parma: Artegrafica Silva.

Barthes, R. 1957. L'Empire de signes. Genève-Paris: Albert Skyra-Flammarion.

Barthes, R. 1984. Centro-città, centro vuoto. In L'impero dei segni. Torino: Einaudi.

Brandão, P., Carrelo M., Águas, S. 2002. O chão da cidade. Guia de avaliação do design de espaço público. Lisboa: Centro Português de Design.

Chabot, C. 1948, Les villes. Paris: Collins.

Choay, F. and P. Merlin. 1988. Dictionnaire de l'urbanisme et de l'aménagement. Paris: Presses universitaires de France.

Choisy, A. 1899. Histoire de l'Architecture. Paris: Gauthier-Villars.

Conforti, P. 1980. Le mura di Parma, vol. II. Parma: Battei. 
De Sessa, C. 1990. Capire lo spazio architettonico. Studi di ermeneutica spaziale. Rome: Officina.

Garzoni, T. 1996. La piazza universale di tutte le professioni del modo, ed. P. Cerchi and B. Collina. Turin: Einaudi.

Gonizzi, G. 2002. I luoghi della storia III. Parma: PPS Editrice.

Halbwachs, M. 1950. La mémoire collective, pref. J. Duvignaud. Paris: Presses Universitaires de France.

Hertzberger, H. 2009. Lessons for Students in Architecture. Rotterdam: 019 Publishers, 12.

Kahn, I. Architettura: silenzio e luce in Bonaiti, M. 2002. Architettura è. Milan: Electa.

Kostof, S. 2009. The City Shaped. Urban Patterns and Meanings through History. London: Thames \& Hudson.

Landsberger, M. 2015. La lezione di Auguste Choisy. Architettura moderna e razionalismo strutturale. Milan: FrancoAngeli.

Lavedan, P. 1936. Géographie des villes. Paris: Gallimard.

Lefebvre, H. 1996. Writings on Cities, ed. E. Kofman and E. Lebas. Oxford: Blackwell.

Leveratto, J. 2018. Dall'interno. Verso un approccio multiscalare all'abitabilità. Siracusa: LetteraVentidue.

Lynch, K. 1960. The Image of the City. Cambridge, MA: Technology Press \& Harvard University Press.

Lynch, K. 1962. What Time Is This Place? Cambridge, MA: MIT Press.

Lynch, K. 1977. Il tempo dello spazio. Milano: Il Saggiatore.

Lynch, K. 1981. A Theory of Good City Form. Cambridge, MA: MIT Press.

Lynch, K. 1990. Progettare la città. La qualità della forma urbana. Milano: Etas.

Massey, D. 2005. For Space. London: Sage.

Mumford, L. 1977. La città nella storia. Milano: Bompiani.

Passarge, S. (ed.). 1930. Stadtlandschaften der Erde. Hamburg: Friederichsen De Gruyter.

Perulli, P. 2009. Visioni di città. Le forme del mondo spaziale. Turin: Einaudi.

Pierini, O. S. 2008. Sulla facciata. Tra architettura e città. Santarcangelo: Maggioli.

Polesello, G. 1989. L'architettura del teatro e i luoghi spazio della città (contemporanea), in La città del teatro, ed. C. Quintelli. Milano: CLUP.

Polesello, G. 1985. L'architettura in funzione, in La geometria in funzione nell'architettura e nella costruzione della città, ed. P. Grandinetti. Venezia: CLUVA.

Portas, N. 2005. Arquitectura(s). Teroia e Desenho, Investigação e Projecto. Porto: Faculdade de Arquitectura da Universidade do Porto.

Quaroni, L. 2019. I volti delle città. Roma: Edizioni di Comunità.

Rizzi, R. 1999. Miseria e Riscatto. La città europea nello sguardo del pensiero. Venezia: Arsenale.

Rossi, A. 1966. L'architettura della città. Padova: Marsilio.

Rossi, A. 1978. L'architettura della città, ed. D. Vitale. Milano: CittàStudi.

Sitte, C. 1889. Der Städtebau nach seinen künstrlerischen Grundsätzen. Wien: Graeser.

Sitte, C. 1952. L'arte di costruire le città, ed. L. Dodi. Milano: Vallardi.

Sommer, R. 1969. Personal Space. The Behavioral Basis of Design. Englewood Cliffs: Prentice Hall.

Tricart, J. 1963. Cours de Géographie Humaine Dasc. II-L'habitat urbain. Paris: Centre de Documentation Universitaire.

Tricart, J. 1998. Corso di geografia umana. Vol. I - L'habitat urbano, ed. M. De Benedetti. Milano: Unicopli.

Vieira de Almeida, P. 1963. Ensaio Sobre o Espaço da Arquitectura. Porto: ESBAP.

Vieira de Almeida, P. 2008. Apontamentos para uma Teoria da Arquitetura. Lisboa: Horizonte.

Zappavigna, P. 2018. Parma 1945-2011. Genesi della città moderna. La politica urbanistica in un resoconto fra cronaca e storia. Parma: Diabasis. 